SŁAWOMIR BANASZAK

Magdalena Andrys

Dorota Dolata

BEATA IWANICKA

ANNA SCHMIDT

Natalia Ulaniecka

Uniwersytet im. Adama Mickiewicza

w Poznaniu

\title{
WSPÓŁCZESNE STUDIA DOKTORANCKIE I WSPÓŁCZEŚNI DOKTORANCI. DONIESIENIA ZE ZWIADU BADAWCZEGO
}

AвSTRAct. Banaszak Sławomir, Andrys Magdalena, Dolata Dorota, Iwanicka Beata, Schmidt Anna, Ulaniecka Natalia, Wspótczesne studia doktoranckie i wspótcześni doktoranci. Doniesienia ze zwiadu badawczego [Modern Doctoral Studies and Their Students. A Pilot Study Report]. Studia Edukacyjne nr 45, 2017, Poznań 2017, pp. 267-279. Adam Mickiewicz University Press. ISSN 1233-6688. DOI: 10.14746/ se.2017.45.18

The article presents the results of a research study on the situation of contemporary post-graduate students. Focus group interviews helped obtain post-graduate students' opinions about the conditions of starting and continuing doctoral studies. The discussion focused on three main topics: motivation to start doctoral studies, the quality and conditions of doctoral studies evaluation, and the advantages and disadvantages of undertaking doctoral studies. Analysis of the respondents' statements shows that the motivations for starting doctoral studies vary strongly. Common in the experience of the interlocutors is a lack of stability in life (including financial stability), insecurity of employment, overload, and stress. However, post-graduate students presented also positive aspects of doctoral studies, e.g.: social prestige or the possibility of development. The last part of the article describes issues related to problems and pathological phenomena (such as 'punctasis' /'points, credits collecting'), pointing to systemic and individual limitations affecting the situation of doctoral students in the Polish tertiary education system.

Key words: focus group interview, doctoral studies, work, development, prestige, aspirations, motivations 


\section{Wprowadzenie}

Niniejszy tekst stanowi rodzaj komunikatu, który jednakże jest komunikatem wstępnym. Dotyczy bowiem nie tyle kompleksowo zorganizowanego i przeprowadzonego badania empirycznego, lecz jedynie zwiadu badawczego. Jest on tu rozumiany jako wstępne badanie, które ma na celu zyskanie ogólnej orientacji o przedmiocie badania oraz samym obiekcie ${ }^{1}$.

A trzeba przyznać, że przedmiot badań, czyli bycie doktorantem, studiowanie, naukowy rozwój i obowiązki dydaktyczne, to zagadnienia ważkie poznawczo i - być może - znaczące praktycznie. Wymiar poznawczy jest związany głównie ze społecznym funkcjonowaniem samych studiów oraz doktorantów. Z kolei wymiar praktyczny jest, naszym zdaniem, istotny z punktu widzenia "czynników władzy”, czyli w tym przypadku rektorów oraz dziekanów, którzy planują, organizują oraz kontrolują przebieg kształcenia na tak zwanym III stopniu studiów. Tym samym, staraliśmy się zachować pewien balans pomiędzy empirią, praktyką społeczną oraz teorią².

Ponadto, aby rozpoznać wstępnie zjawiska i procesy wiążące się, by tak rzec, z życiem doktoranta, wybraliśmy technikę zogniskowanego wywiadu grupowego. Daje ona sposobność inicjowania dyskusji, wglądu w interakcje uczestników w czasie sesji, tworzy również możliwość obserwacji, a następnie analizy i interpretacji zachowania badanych ${ }^{3}$. Może stanowić technikę autonomiczną lub uzupełniającą. W naszym zwiadzie badawczym sesja fokusowa stanowiła technikę samodzielną, ale występującą z planową obserwacją.

Wartą podkreślenia modyfikacją była także okoliczność moderowania sesji przez dwie moderatorki, a nie, jak to zwykle ma miejsce, przez jedną osobę. Zdecydowaliśmy się na ten zabieg z dwóch powodów. Po pierwsze, sztuczna sytuacja spotkania doktorantów (uczestników i moderatora) przy jednym stole nie sprzyja w naszej opinii „otwarciu się" respondentów. Tym bardziej, że badanie dotyczyło względnie rozległej problematyki wyborów życiowych. Uznaliśmy więc, że dwie moderatorki będą w stanie stworzyć bardziej sprzyjający klimat do dyskusji.

Drugim argumentem było doświadczenie badawcze moderatorek i obawy związane z podjęciem się zadania samodzielnego prowadzenia sesji. Trzeba

\footnotetext{
${ }^{1}$ S. Nowak, Metodologia badań społecznych, Warszawa 2012.

2 S. Banaszak, Teoria i empiria - kilka uwag metodologicznych i praktycznych, [w:] Pedagogika jako humanistyczno-spoteczna nauka stosowana: konsekwencje metodologiczne, red. D. Kubinowski, M. Chutoriański, Kraków 2017. W zakresie relacji wzajemnych między empirią a praktyką por. też: S. Banaszak, Edukacja menedżerska w społeczeństwie wspótczesnym. Studium teoretyczno-empiryczne, Poznań 2011.

${ }^{3}$ Por. D. Silverman, Interpretacja danych jakościowych. Metody analizy rozmowy, tekstu i interakcji, przekł. M. Głowacka-Rajper, J. Ostrowska, Warszawa 2009. Por. też: J. Lisek-Michalska, Badania fokusowe. Problemy metodologiczne i etyczne, Łódź 2013.
} 
jednak przyznać, że ich przygotowanie, przeszkolenie oraz znajomość „od wewnątrz" zagadnień związanych z przedmiotową problematyką zaowocowały bardzo żywiołową dyskusją, kontrolą tej dyskusji, przy jednoczesnym zagwarantowaniu swobody uczestników, a także wydobyciem niezwykle istotnych faktów. Skłania to do wniosku natury metodologicznej w zakresie studium samej techniki gromadzenia danych: w sytuacjach szczególnych, drażliwych tematów, specyficznej kompozycji uczestników badania, moderowanie sesji fokusowej przez dwóch moderatorów byłoby wręcz pożądane.

\section{Studia doktoranckie - rozwój, prestiż, aspiracje i motywacje}

Rozwój jest terminem niezwykle szerokim, który przez Józefa Kozieleckiego utożsamiany jest $\mathrm{z}$ "procesem zmian progresywnych zachodzących w czasie" ${ }^{\prime 4}$. Należy jednak zwrócić uwagę, że, jak podaje H. Rudolph Schaffer, o rozwoju mówi się nie tylko w przypadku zmian progresywnych, lecz także w przypadku regresji ${ }^{5}$. Z kolei Janusz Trempała definiuje rozwój w następujący sposób: „proces systematycznych zmian w zachowaniu (różnic wewnątrzi międzyosobniczych), które występują wraz z upływem czasu w ciągu życia organizmu"6.

Niezależnie od sposobu definiowania terminu „rozwój”, należy zgodzić się, że jest on procesem długotrwałym, który nie kończy się w określonym wieku jednostki bądź w momencie uzyskania przez nią określonych dyspozycji. Jak wskazuje Anna Brzezińska: „w każdym kolejnym okresie rozwoju kierowane są ku niemu inne oczekiwania społeczne, inne bowiem wymagania stawia mu najbliższe środowisko, w którym żyje $(. . .)^{\prime \prime}$.

W konsekwencji należałoby zwrócić uwagę, że wspomniane zmiany, dokonujące się $\mathrm{w}$ jednostce, mogą być spowodowane zarówno działaniem czynników wewnętrznych, jak również zewnętrznych ${ }^{8}$. Do grupy czynników zewnętrznych, warunkujących rozwój jednostki, można zaliczyć specyfikę jej relacji interpersonalnych, jak również rozwój osobisty, który dość intensywnie eskaluje $\mathrm{w}$ działaniach danej osoby podejmowanych celem poszerzania

\footnotetext{
${ }^{4}$ J. Kozielecki, Koncepcje psychologiczne człowieka, Warszawa 1995, s. 30.

${ }^{5}$ H.R. Schaffer, Psychologia rozwojowa. Podstawowe pojęcia, Kraków 2010, s. 2.

${ }^{6}$ J. Trempała, Natura rozwoju psychicznego, [w:] Psychologia rozwoju człowieka, red. J. Trempała, Warszawa 2011, s. 49.

7 A. Brzezińska, Portrety psychologiczne człowieka. Jak zmienia się człowiek w ciagu życia? Remedium, 2003, 4(122), s. 3.

${ }^{8}$ O. Gazińska, Rozwój człowieka a rozwój średnich miast europejskich w kierunku miasta inteligentnego na przykładach Jönköping i Szczecina, [w:] Architektura a rozwój człowieka. Ujęcie multidyscyplinarne, red. A. Kalus, E. Mazurek, J. Szymańska, Wrocław 2015, s. 49.
} 
jej wiedzy i umiejętności. Są one zauważalne w okresie szkolnym, a później w podejmowanej przez nią dalszej edukacji i działalności zawodowej. Ta z kolei najintensywniej przejawia się w okresie dorosłości człowieka, czyli $\mathrm{w}$ przedziale wiekowym, który wykazuje zależność $\mathrm{z}$ wiekiem opisywanych w niniejszym artykule jednostek badanych. Jak wskazują Anna Brzezińska, Karolina Appelt oraz Beata Ziółkowska, „praca to konstruktywne zachowanie celowe, które może się pojawiać także w kontekście pozazawodowym" ${ }^{\prime \prime}$.

Należy przyznać, że to bardzo - mówiąc najdelikatniej - nieklasyczna definicja pracy, która abstrahuje od środków zapewniających stałe utrzymanie. Redukuje pracę do każdego celowego zachowania, co raczej trudno uznać za definicję przydatną w praktyce. Spacer lub taniec byłyby w zamyśle autorek tej oryginalnej koncepcji także pracą. Niemiej warto zgodzić się z tezą, której nie da się chyba wiązać jedynie ze wspomnianymi autorkami, że praca nie musi być wyłącznie wykonywana w miejscu zatrudnienia jednostki, może być także podejmowana na przykład w domu. Pracą będzie więc również poszerzanie wiedzy $\mathrm{w}$ toku samokształcenia, na co zresztą zwracali uwagę uczestnicy sesji fokusowej.

Aktywność zawodowa, podejmowanie pracy jest wyznacznikiem prawidłowego rozwoju w dorosłości ${ }^{10}$. Dzięki niej jednostka może zaspokoić swoje potrzeby indywidualne, jak również potrzeby społeczne. Dobrze wykonywana praca, będąca dla jednostki źródłem przyjemności, satysfakcji, ma niebagatelny wpływ na jej dobrostan i rozwój psychiczny ${ }^{11}$. Zatem, poszerzanie własnych umiejętności oraz poszerzanie wiedzy wykazuje wzajemne relacje z pojęciem pracy. To z kolei przyczynia się do rozwoju jednostki, czyli dokonywania u niej zmian zarówno w wymiarze indywidualnym, jak i społecznym. Przygotowując sesję fokusową uznaliśmy, że motywacją do podejmowania studiów trzeciego stopnia przez jednostki dobrane do badania może być chęć dalszego rozwoju.

Kolejnym powodem kształcenia $\mathrm{w}$ ramach studiów doktoranckich może być prestiż, który, podobnie jak termin rozwój, jest pojęciem wieloznacznym. Można go ujmować zarówno jako zjawisko, relację, bądź cechę. Na przykład, prestiż społeczny jako zjawisko polega, w ujęciu Tadeusza Pilcha, na „,symbolicznym okazywaniu wyższości, równości albo niższości społecznej ludziom ze względu na ich role społeczne bądź przynależność do pewnych kategorii społecznych (np. zawodowych lub klasowych)"12. Z kolei prestiż rozumiany jako relacja polega na okazywaniu i odbieraniu przez ludzi symbolicznych

9 A.I. Brzezińska, K. Appelt, B. Ziółkowska, Psychologia rozwoju człowieka, Gdańsk 2015, s. 325 .

${ }^{10}$ E. Gurba, Wczesna dorostość, [w:] Psychologia rozwoju człowieka, red. J. Trempała, Warszawa 2011, s. 297.

${ }^{11}$ L. Bakiera, Ż. Stelter, Leksykon psychologii rozwoju człowieka, t. 2, Warszawa 2011, s. 83.

${ }_{12}$ T. Pilch, Encyklopedia pedagogiczna XXI wieku, t. IV, Warszawa 2005, s. 885. 
zachowań w obrębie określonego porządku prestiżowego. Przykładem może być używanie tytułów naukowych w komunikacji z daną osobą. Jako cecha danej jednostki prestiż pogłębia dystanse społeczne oraz doprowadza do wzmacniania barier społecznych ${ }^{13}$.

Znaczenie omawianego terminu zazwyczaj wikła dodatkowe pojęcia, w szczególności szacunek i uznanie. Odwołując się do słownika pedagogicznego, prestiż oznacza „uznanie i szacunek społeczny dla określonej jednostki lub grupy, związany z jej pozycją (wysoką) w hierarchii społecznej"14. Do wspomnianego okazywania szacunku w konsekwencji prestiżu społecznego wobec danej jednostki Stanisław Ossowski wskazuje, że „reakcje psychiczne nie podlegają bezpośredniej kontroli innych ludzi, więc przywilej prestiżu społecznego jest przywilejem odbierania zewnętrznych oznak szacunku"15.

Współcześnie wskazuje się na fakt, że prestiż wiąże się z pozycją społeczną danej jednostki, jak również z jej położeniem ekonomicznym. Podkreśla się przy tym, że ludzie zajmujący wysoką pozycję w hierarchii społecznej są zamożni, bądź wykonują szczególnie uznany zawód, cieszą się szacunkiem i podziwem ${ }^{16}$. W odniesieniu do opisywanej w niniejszym artykule kategorii społecznej, jak wskazują badania Centrum Badania Opinii Społecznej, jej status jest tym, który najbardziej cieszy się prestiżem społecznym, zaraz po zawodzie strażaka ${ }^{17}$. Można więc dowieść, że podjęcie studiów doktoranckich wiąże się w opinii społecznej z prestiżem akademików, okazywaniem im szacunku oraz uznania społecznego, co może być z kolei jednym z motywatorów do podjęcia kształcenia na tym szczeblu edukacji uniwersyteckiej.

Podjęcie decyzji o dalszej aktywności edukacyjnej, w tym wypadku podjęcie studiów trzeciego stopnia, jest warunkowane przez aspiracje. Są one ważnym elementem $\mathrm{w}$ procesie rozwoju osobowości człowieka i jednym z najistotniejszych czynników warunkujących jego aktywność. Szeroko rozumiane aspiracje mają wpływ na aktywność społeczną, kulturalną, a także na sieć nawiązywanych kontaktów interpersonalnych. Aspiracje wpływają na zdobywane osiągnięcia, wybór szkoły, zawodu, studiów. Aspiracje odgrywają zatem role $\mathrm{w}$ kształtowaniu się planu życiowego oraz orientacji życiowej danej jednostki ${ }^{18}$. Wpływają także na przyjęte dążenia, pragnienia oraz oczekiwania rozwijającej się jednostki. Oparcie dla aspiracji może stanowić ambicja i pewna wiara we własne możliwości i talenty. Aspiracja

${ }_{13}$ Tamże.

${ }^{14}$ Tamże, s. 884.

${ }^{15}$ S. Ossowski, Zagadnienia struktury społecznej, Warszawa 1968, s. 24.

${ }^{16}$ T. Pilch, Encyklopedia pedagogiczna XXI wieku, s. 884.

17 A. Cybulska, CBOS, Prestiż zawodów, Warszawa 2013, s. 3.

18 A. Zawada, Aspiracje życiowe młodzieży w środowisku kulturowo zróżnicowanym, KrakówKatowice 2013, s. 14. 
łączy się z potrzebą sukcesu, dokonania jakiegoś znaczącego osiągnięcia życiowego $^{19}$.

Aspiracje wyznaczają zatem cele, do których dąży dany człowiek. Na rynku pracy można wyróżnić wiele aspiracji pracowników. Do najczęstszych zalicza się: pewność (stabilność) zatrudnienia, wysokie wynagrodzenie, poczucie samorealizacji, poczucie urozmaicenia w pracy, zdobycie społecznego uznania i szacunku, możliwość uczenia się i rozwoju zawodowego ${ }^{20}$.

Część wspomnianych oczekiwań, składających się na aspiracje współczesnego doktoranta, można by z pewnością potwierdzić. Zapewne większość studentów III stopnia przygotowując swoją pracę doktorską i uczestnicząc w zajęciach na swoim macierzystym Studium Doktoranckim, jest nastawionych na idące za tym poczucie samorealizacji oraz na możliwość stałego uczenia się i podnoszenia umiejętności badawczych. Dla wielu osób stopień naukowy doktora niesie ze sobą pewien społeczny szacunek, a możliwość posługiwania się nim może zwiększać poczucie własnej wartości.

Aspiracje te stanowią ważną składową oczekiwań współczesnego doktoranta. Dyskusyjna jest natomiast kwestia stabilności zatrudnienia. Świadomość, że studia doktoranckie muszą się zakończyć po upływie czterech lat, z ewentualną perspektywą rocznego przedłużenia, powoduje, że nie można kojarzyć pracy doktoranta z długoterminową stabilnością. Po pierwsze, nie wszyscy doktoranci kończą studia i bronią prace doktorskie. Z kolei ta część, która pomyślnie finalizuje swoje starania, nie zawsze zyskuje etatowe zatrudnienie w macierzystej jednostce badawczej.

Przechodząc do operacyjnej definicji motywacji, rozumiemy ją jako emocjonalno-poznawczą postawę, która ukierunkowuje zamierzone działanie konkretnej osoby na osiągnięcie wyznaczonego celu, uwzględniając także cały kontekst społeczno-kulturowy ${ }^{21}$. Motywacja to zatem tendencja do osiągania i przekraczania standardów doskonałości, związana z odczuwaniem pozytywnej emocji w sytuacjach zadaniowych, spostrzeganych jako wyzwanie ${ }^{22}$.

W procesie motywowania można z kolei rozróżnić dwa podejścia: rezultatowe, wówczas motywacja jest pewnym stanem napięcia, oraz czynnościowe, czyli związane ze świadomym i celowym oddziaływaniem na innych ludzi. Generalnie rzecz ujmując, motywacja jest stałą dyspozycją człowieka w zachowaniach ukierunkowanych na pracę i zaspokajanie swoich potrzeb. Odpowiada za podtrzymywanie postawy człowieka, zmierzającego w określonym kierunku' ${ }^{23}$.

${ }^{19}$ D. Wiśniewski, Aspiracje młodzieży ponadgimnazjalnej w kontekście zmian kulturowych, Toruń 2012, s. 13-14.

${ }^{20}$ P. Górski, Aspiracje zawodowe studentów socjologii i zarzadzania AGH w świetle badań ankietowych, [w:] Nierówności społeczne a wzrost gospodarczy, red. M. Gabriel-Woźniak, Rzeszów 2003, s. 35.

${ }^{21}$ W. Smid, Ontologia sukcesu, Kraków 2011, s. 33.

${ }^{22}$ W. Kozłowski, Cele i osiagnięcie w uczeniu się, Warszawa 2006, s. 8.

23 Z. Sekuła, Motywowanie do pracy. Teorie i instrumenty, Warszawa 2008, s. 11. 


\section{Przebieg badania}

Sesja zogniskowanego wywiadu grupowego odbyła się 6 kwietnia 2017 roku w przystosowanej do tego typu badań sali fokusowej, mieszczącej się w budynku Wydziału Studiów Edukacyjnych Uniwersytetu im. Adama Mickiewicza w Poznaniu. Moderatorki rozpoczęły badanie od przedstawienia się, zapoznały uczestników z celem spotkania i poinformowały o rejestrowaniu jego przebiegu za pomocą kamer i mikrofonów. Omówiły także inne kwestie organizacyjne. Ponadto, przekazano uczestnikom informację, że za lustrem weneckim znajdują się inni badacze, którzy będą obserwować spotkanie. Wszyscy uczestnicy, po wysłuchaniu powyższych informacji, ponownie potwierdzili chęć wzięcia udziału w badaniu.

Następnie, w celu ułatwienia rozmowy, uczestnicy zostali poproszeni o zapisanie swoich imion na identyfikatorach, przedstawienie się i powiedzenie kilku słów o sobie (wydział, rok studiów doktoranckich, dziedzina naukowa, zainteresowania). Przy tej okazji jeden z uczestników opowiedział, że zajmuje się marketingiem swojego wydziału i rozdał pozostałym osobom długopisy z logo swojej uczelni. Następnie moderatorki poprosiły o otworzenie teczek znajdujących się przed uczestnikami. Każda teczka zawierała ten sam zestaw ponumerowanych materiałów (memy internetowe, fragmenty artykułów, pisemne zadania aktywizujące), które stanowiły punkt wyjścia do dyskusji.

Sesja trwała dwie godziny, w czasie których uczestnicy chętnie brali udział w dyskusji, dzieląc się swoimi doświadczeniami, spostrzeżeniami i uwagami dotyczącymi omawianych tematów. Można wskazać kilka osób dominujących $\mathrm{w}$ dyskusji oraz osoby relatywnie bardziej pasywne. Osoby mniej angażujące się w dyskusję były (w trosce o pozyskanie szerokiego spektrum odpowiedzi) aktywizowane przez prowadzące, które dbały, aby każdy uczestnik miał równe prawo głosu w dyskusji.

Niestety, można było zaobserwować momenty, w których dwóch uczestników spotkania nie przejawiało zainteresowania wypowiedziami innych i kontynuowało rozmowę między sobą. Fakt ten był również monitorowany przez moderatorki na podstawie początkowych ustaleń dotyczących kultury dyskusji.

Sesja fokusowa, zgodnie z przygotowanym wcześniej scenariuszem badania, ogniskowała się wokół następujących głównych obszarów:

1. Motywacje do podjęcia studiów doktoranckich.

2. Ocena jakości i warunków studiowania na III stopniu.

3. Zalety i wady podejmowania studiów doktoranckich.

Pierwszy temat dyskusji dotyczył stereotypów odnośnie doktorantów oraz reakcji otoczenia na decyzję o podjęciu studiów doktoranckich. Inspiracją do 
dyskusji były memy internetowe w humorystyczny sposób kwestionujące sens i wartość doktoratu. Następnie uczestnicy przedstawili swoje indywidualne motywy podjęcia studiów doktoranckich.

Kolejnym polem do rozmów była próba odpowiedzi na pytania: Czy doktorat jest osiągnięciem, a same studia doktoranckie wiążą się z prestiżem? Czy warto przyznawać się do bycia doktorantem? Niezwykle ważnym elementem dyskusji, często przewijającym się $\mathrm{w}$ wypowiedziach (również $\mathrm{w}$ odniesieniu do innych pytań), były kwestie związane z zabezpieczeniem finansowym i socjalnym doktorantów oraz możliwością założenia rodziny. Dyskusja ta zapoczątkowała z kolei wątek strategii i modeli studiowania w kontekście balansowania pomiędzy tym co się opłaca krótkoterminowo, czyli „żeby uzyskać stypendium", a rzetelnym, lecz czasochłonnym podejściem do pisania pracy doktorskiej (kosztem natychmiastowych profitów i stypendium).

Opisano patologie systemu, które można zamknąć w pojęciu tak zwanej „punktozy”, czyli presji zdobywania punktów według narzuconego odgórnie klucza, który premiuje konkretne działania, na przykład wyjazdy na konferencje czy częste publikowanie. To z kolei powoduje swoiste odwrócenie istoty systemu punktowego: doktoranci swoją aktywność naukową uzależniają nie od zidentyfikowania, co będzie dla nich wartościowe z punktu widzenia jakości ich pracy badawczej, lecz od tego, co jest najbardziej opłacalne punktowo i pozwoli im uzyskać wysokie miejsce $\mathrm{w}$ rankingu opartym na tychże punktach ${ }^{24}$.

Kolejnym poruszanym tematem był status doktorantów, który można określić jako swoiste zawieszenie pomiędzy studentem a pracownikiem. Uczestnicy omówili również stosunki pomiędzy doktorantami, a także relacje na linii doktorant-promotor oraz doktorant-władze uczelniane. Przedstawili także swoje plany na przyszłość oraz oczekiwania względem kariery uniwersyteckiej.

Końcowa część dyskusji została oparta na zadaniu polegającym na opisaniu korzyści i wad studiów doktoranckich oraz wyszczególnieniu i rangowaniu cech osobowościowych szczególnie przydatnych podczas studiów doktoranckich. Część zasadniczą badania zakończyła burza mózgów dotycząca porad dla przyszłych potencjalnych doktorantów.

Zamykając sesję, prowadzące podziękowały uczestnikom za poświęcony czas, otwartość i podzielenie się swoimi przemyśleniami. Poinformowały również o planowanej publikacji wyników badań oraz poprosiły osoby zainteresowane

${ }^{24}$ Warto w tym miejscu przywołać również stwierdzenie E. Kulczyckiego, który zjawisko to definiuje w następujący sposób: Punktoza to takie definiowanie celów badawczych, aby ich wyniki byly publikowalne bez znaczacego wysiłku ze strony naukowca. Jedną z głównych przyczyn punktozy jest funkcjonowanie (najczęściej parametrycznego) systemu ewaluacji nauki w danej społeczności akademickiej oraz deinstytucjonalizacja misji badawczej uczelni (...). Punktoza jest syndromem "chorej nauki", w której nie prowadzi się badań, ale trzeba publikować "cokolwiek", gdyż na podstawie publikacji pracownik jest rozliczany; E. Kulczycki, Punktoza jako strategia w grze parametrycznej w Polsce, Nauka i Szkolnictwo Wyższe, 2017, 1(49), s. 68. 
ich otrzymaniem o pozostawienie kontaktu mailowego. Następnie uczestnikom wręczono upominki (gadżety Wydziału Studiów Edukacyjnych i Uniwersytetu im. Adama Mickiewicza w Poznaniu). Warto podkreślić, że podczas badania panowała przyjazna atmosfera, dzięki której - jak stwierdzili sami uczestnicy zapomnieli, że ich wypowiedzi są nagrywane. Sądzimy, że ten fakt pozytywnie wpłynął tak na swobodę wypowiedzi, jak i na dynamikę rozmów.

\section{Wyniki i wnioski}

Dlaczego studenci wybierają studia III stopnia? Motywacji do podjęcia studiów doktoranckich może być bardzo wiele. Wśród osób badanych pojawiały się takie aspekty, jak: prestiż społeczny związany z uzyskanym tytułem, realizacja swoich planów zawodowych czy koncepcji pracy naukowo-badawczej, perspektywa wyższych zarobków oraz otrzymania etatu na uniwersytecie, sugestie ze strony rodziny, ale również spontaniczne decyzje podejmowane $\mathrm{w}$ wyniku braku pomysłu na swoją przyszłość, czy motywowane propozycjami otrzymanymi od przyszłych promotorów, kierowników zakładów/pracowni/katedr/instytutów lub jak na przykład w przypadku studiów prawniczych podążanie jedną z dróg umożliwiających przystąpienie do egzaminu aplikanckiego.

Można więc zauważyć, że powody, dla których doktoranci wybierają studia III stopnia, są zróżnicowane. Często ściśle zdeterminowane osobistą sytuacją studenta, jak i szczególną specyfiką poszczególnych uczelni oraz kierunku, który reprezentuje. Nie zawsze są powiązane z tak wydawałoby się oczywistym faktem zdobywania wiedzy, a także rozwoju i samorealizacji w zakresie pracy naukowo-badawczej.

Czy zatem warto podejmować studia doktoranckie? Jakiej rady udzieliłyby osoby biorące udział w badaniu kandydatom na studia III stopnia? Jakie korzyści oraz straty wynikają z dalszej edukacji akademickiej? Wśród zalet badani wskazywali takie aspekty, jak: prestiż społeczny, możliwość rozwoju, poznawanie nowych, ciekawych ludzi, realizowanie swoich pasji, poszerzanie horyzontów i perspektyw działania, zdobywanie wiedzy i doświadczenia, a także satysfakcja z efektywnego nauczania studentów.

Wśród wad pojawiły się: brak stabilizacji finansowej i wynikające z niej problemy, zbyt mało czasu wolnego na odpoczynek oraz pisanie pracy/artykułów/własną działalność naukowo-badawczą, natłok dodatkowych obowiązków zlecanych przez przełożonych, ogólne zmęczenie spowodowane nadmiarem pracy i stresem oraz małe perspektywy podjęcia dalszej pracy na uniwersytecie. Badani nie udzielili jednoznacznej odpowiedzi, czy warto podejmować studia doktoranckie czy z nich rezygnować. Podawali jedynie 
rady, które skierowaliby do potencjalnych kandydatów. Oto niektóre z nich: „Twórz własne środowisko świadomie”, , Zastanów się, w jakim miejscu widzisz się za cztery lata - to zweryfikuje Twoją decyzję o podjęciu studiów doktoranckich”, "Nie patrz na innych!”, „Bądź sobą, ale dobrze wybierz za$\mathrm{kład/katedrę/instytut",} \mathrm{„Nie} \mathrm{bądź} \mathrm{bierny!”,} \mathrm{"Staraj} \mathrm{się} \mathrm{pisać} \mathrm{w} \mathrm{zgodzie} \mathrm{ze}$ sobą". Podkreślili również, że dużą satysfakcję daje im prowadzenie zajęć i kontakt ze studentami.

Jaki obraz doktoranta wyłania się z dyskusji wśród badanych. Uczestnicy sesji zostali poproszeni o wybranie z listy najważniejszych i najbardziej potrzebnych ich zdaniem cech doktoranta, niezbędnych w czasie realizacji studiów III stopnia. Z wypełnionych arkuszy można wyprowadzić wniosek, iż doktorant powinien być: ambitny („Sięgaj tam, gdzie wzrok jeszcze nie sięga...”), dobrze zorganizowany („Żeby nie zginął w natłoku wydarzeń i obowiązków"), odpowiedzialny (za to, co publikuje i co mówi na wystąpieniach konferencyjnych...), wytrwały (w pisaniu dysertacji...), twórczy („Najlepiej pisz i rób coś, czego nikt inny jeszcze nie odkrył..."), bystry (w poszukiwaniu grantów, konkursów i zdobywaniu punktów do stypendiów), uparty (w dążeniu do osiągnięcia zamierzonego celu, czyli długo wyczekiwanej obrony...) oraz rzetelny (w swoich WSZYSTKICH działaniach). Dobrze, by wykazywał się również wyrozumiałością (w szczególności w kontekście negatywnej decyzji o przyznaniu stypendium rektora...), pracowitością, a także by był pomocny („Dla chwały wydziału, zakładu i całej uczelni!”) i punktualny (czas to pieniądz...).

Na dalszym planie sytuowały się takie cechy, jak: cierpliwość (w oczekiwaniu na wydanie artykułu w czasopiśmie punktowanym...), posłuszeństwo (w szczególności w relacji z promotorem i władzami dziekańskimi...), wszechstronność (musi potrafić wszystko), czynności organizacyjne, porządkowe (Wszystko, tylko nie to, co trzeba... Czyli kiedy tu pisać, kiedy tyle się dzieje...), bycie godnym zaufania i przyjaznym (relacja z koleżankami i kolegami z roku, wykładowcami, paniami w dziekanacie...) oraz dyspozycyjność (nigdy nie wiesz, co jeszcze na ciebie czeka i kiedy promotor zadzwoni...).

Badani zostali zapytani o pracę, finanse i możliwość założenia rodziny. Doktoranci byli zgodni, że pytania dotyczące powyższych obszarów są najczęściej zadawane przez rodzinę, znajomych, a także nowo poznane osoby. Czy istnieje możliwość połączenia studiów doktoranckich z założeniem rodziny? Wyrażono zgodnie opinię, że „Nie ma szans!” Argumenty za tym przemawiające, to przede wszystkim brak czasu, ciągły pośpiech, a także brak stabilnej sytuacji mieszkaniowej oraz finansowej. Sytuacja, w której doktorant zakłada rodzinę, wiązałaby się z koniecznością przerwy (szczególnie w przypadku kobiet), a także z przymusem podjęcia dodatkowej, najlepiej dobrze płatnej pracy (często zdalnej - wykonywanej w nieokreślonych godzinach), 
co mogłoby kolidować z prawidłowym i pożądanym funkcjonowaniem rodziny, a także pisaniem rozprawy, uczęszczaniem na wykłady i prowadzeniem zajęć.

Sposobem na stabilniejszą sytuację mogłoby być zatrudnienie na uczelni, jednakże doktoranci mają świadomość, iż to rozwiązanie jest nierealne. Zdają sobie również sprawę, że po ukończeniu studiów i obronie dysertacji bardzo trudno o etat i że udaje się to nielicznym. Minusem wskazanym przez badanych jest fakt, iż ze względu na nikłe perspektywy pracy na uczelni (czyli brak możliwości dalszego rozwoju), po studiach III stopnia (ze stopniem doktora) w wieku dwudziestu ośmiu lat młody człowiek zmuszony jest wejść na rynek pracy bez doświadczenia (zakładając, że wcześniej oddany był jedynie studiom).

Rozmowa o zatrudnieniu wzbudziła refleksję na temat statusu doktoranta na uczelni, który jest często zależny od sytuacji. Czy więc bliżej doktorantowi do pracownika czy do studenta? W odniesieniu do prowadzenia zajęć traktowani są jak inni pracownicy - zarówno pod względem organizacyjnym, jak i merytorycznym (nie uzyskując wynagrodzenia). Zdarza się jednak usłyszeć „jesteście tylko studentami III stopnia”. Pewnym momentem zmiany w sposobie traktowania jest otwarcie przewodu doktorskiego, w którym doktorant zostaje przedstawiony szerszemu gronu kadry profesorskiej, ma formalnie ukonstytuowanego promotora oraz znany jest jego obszar pracy badawczej. Powody te mają wpływ na pewnego rodzaju identyfikację w środowisku wydziałowym.

Jak wskazywali badani, bycie doktorantem, nawet w sytuacji otrzymywania stypendium podstawowego, projakościowego lub innego, dopiero po podjęciu dodatkowej, "normalnej pracy” (najczęściej niezwiązanej z kierunkiem studiów), można zacząć planować wynajem innego mieszkania (większy metraż, wyższy standard, lepsza okolica). Zakup mieszkania, niesponsorowany przez najbliższą rodzinę, jest niestety nierealny (brak zatrudnienia, nikłe szanse na kredyt). Temat związany $\mathrm{z}$ finansami zainicjował jednocześnie dyskusję dotyczącą kryteriów stypendialnych i wyścigu punktowego, w jakim doktoranci zmuszeni są uczestniczyć, żeby uzyskać stypendium.

W zależności od uczelni/wydziału kryteria przyznawania stypendium są odmienne (np. na niektórych uczelniach i kierunkach na I roku nikt nie dostaje stypendium; na innych przypadają np. cztery stypendia na wszystkich studentów jednego roku; w Akademii Muzycznej najistotniejszym kryterium jest liczba koncertów). Na pozytywną decyzję komisji stypendialnej wpływa znacznie czynny udział w konferencjach naukowych. Doktoranci uczestniczący w badaniu odnieśli się również do tego zagadnienia podkreślając, że jest to nieodłączny element „punktozy”. Konieczność zdobywania punktów prowadzi do sytuacji, w której doktoranci wybierają te najbardziej 
„opłacalne” konferencje, na które jeżdżą i wygłaszają 10-15-minutowe referaty (często w formie podręcznikowego odczytu). Rekordziści w ciągu roku akademickiego potrafią uczestniczyć w piętnastu konferencjach (w wypadku muzyków zdarzają się nawet trzy koncerty dziennie). Podobnie wygląda kwestia artykułów naukowych, ich poziomu merytorycznego oraz praktycznej przydatności.

Powyższe czynniki wpływają również na atmosferę i relacje panujące wśród doktorantów w ramach jednego rocznika, a także całego kierunku. Widoczne i odczuwalne są podziały wynikające z tej rywalizacji. Podczas badania uczestnicy podzielili się także historiami, które opatrywali tytułami: „rzucanie kłód pod nogi” lub „rozsiewanie brutalnych plotek”.

W opinii badanych, program studiów III stopnia oraz przedmioty w nim zawarte zwykle tematyką odbiegają od obranych przez nich kierunków rozwoju. Na ich przydatność i atrakcyjność w dużej mierze mają wpływ prowadzący. Natomiast, bolączką są przedmioty ogólnouniwersyteckie, których treści bywają zazwyczaj abstrakcyjne i niestety obierane z konieczności na zasadzie "trzeba to zaliczyć".

\section{Zakończenie}

Badanie tak interesujących kategorii, jak doktoranci nie należy raczej do głównego nurtu empirycznych badań w naukach społecznych. Szkoda, bo już niniejszy zwiad badawczy unaocznił liczne problemy, z którymi borykają się doktoranci. A także te, z którymi boryka się uczelnia organizująca kształcenie w ramach tak zwanego III stopnia.

Badawcze wnioski są tak rozległe, jak rozległa problematyka stała się inspiracją do podjęcia opisywanej próby empirycznej. Osobny temat, który rekomendujemy przyszłym badaczom, stanowi język doktorantów, zarówno pod względem poprawności i czystości reguł, jak i komunikatywności merytorycznej. Opisywana kategoria osób wykazywała pod tym względem duże zróżnicowanie.

Odnosząc się do trafności wyboru techniki otrzymywania danych, należałoby fokus określić jako w pełni adekwatny i dający wgląd nie tylko w opinie, lecz także w głębiej leżące motywacje, opisywane postawy i wyrażane emocje. Wszystko to stanowi łącznie skomplikowaną strukturę pozycji i ról pełnionych tak w ramach uczelni, jak i poza nią. Skłonność oraz zdolność do dyskusji badanej kategorii osób wydobyła z niej to co istotne i co pozwala wnioskować o położeniu doktoranta w polskim systemie edukacji akademickiej. 


\section{BIBLIOGRAFIA}

Bakiera L., Stelter Ż., Leksykon psychologii rozwoju człowieka, t. 2, Wydawnictwo Difin, Warszawa 2011.

Banaszak S., Edukacja menedżerska w społeczeństwie wspótczesnym. Studium teoretyczno-empiryczne, Wydawnictwo Naukowe UAM, Poznań 2011.

Banaszak S., Teoria i empiria - kilka uwag metodologicznych i praktycznych, [w:] Pedagogika jako humanistyczno-społeczna nauka stosowana: konsekwencje metodologiczne, red. D. Kubinowski, M. Chutoriański, Oficyna Wydawnicza Impuls, Kraków 2017.

Brzezińska A., Portrety psychologiczne człowieka. Jak zmienia się człowiek w ciagu życia? Remedium, 2003, 4(122).

Brzezińska A.I., Appelt K., Ziółkowska B., Psychologia rozwoju człowieka, Gdańskie Wydawnictwo Psychologiczne, Gdańsk 2015.

Cybulska A., CBOS, Prestiż zawodów, Fundacja CBOS, Warszawa 2013.

Gazińska O., Rozwój człowieka a rozwój średnich miast europejskich w kierunku miasta inteligentnego na przykładach Jönköping i Szczecina, [w:] Architektura a rozwój człowieka. Ujęcie multidyscyplinarne, red. A. Kalus, E. Mazurek, J. Szymańska, Wydawnictwo Politechniki Wrocławskiej, Wrocław 2015.

Górski P., Aspiracje zawodowe studentów socjologii i zarządzania AGH w świetle badań ankietowych, [w:] Nierówności społeczne a wzrost gospodarczy, red. M. Gabriel-Woźniak, Uniwersytet Rzeszowski, Rzeszów 2003.

Gurba E., Wczesna dorostość, [w:] Psychologia rozwoju człowieka, red. J. Trempała, Wydawnictwo Naukowe PWN, Warszawa 2011.

Kozielecki J., Koncepcje psychologiczne człowieka, Wydawnictwo Akademickie Żak, Warszawa 1995.

Kozłowski W., Cele i osiagnięcie w uczeniu się, Wydawnictwo SGGW, Warszawa 2006.

Kulczycki E., Punktoza jako strategia w grze parametrycznej w Polsce, Nauka i Szkolnictwo Wyższe, 2017, 1(49).

Nowak S., Metodologia badań społecznych, Wydawnictwo Naukowe PWN, Warszawa 2012.

Ossowski S., Zagadnienia struktury społecznej, Państwowe Wydawnictwo Naukowe, Warszawa 1968.

Pilch T., Encyklopedia pedagogiczna XXI wieku, t. IV, Wydawnictwo Akademickie Żak, Warszawa 2005.

Sekuła Z., Motywowanie do pracy. Teorie i instrumenty, Polskie Wydawnictwo Ekonomiczne, Warszawa 2008.

Schaffer H.R., Psychologia rozwojowa. Podstawowe pojęcia, Wydawnictwo Uniwersytetu Jagiellońskiego, Kraków 2010.

Smid W., Ontologia sukcesu, Orlex, Kraków 2011.

Trempała J., Natura rozwoju psychicznego, [w:] Psychologia rozwoju człowieka, red. J. Trempała, Wydawnictwo Naukowe PWN, Warszawa 2011.

Wiśniewski D., Aspiracje młodzieży ponadgimnazjalnej w kontekście zmian kulturowych, Wydawnictwo Adam Marszałek, Torun 2012.

Zawada A., Aspiracje życiowe młodzieży w środowisku kulturowo zróżnicowanym, Oficyna Wydawnicza Impuls, Kraków-Katowice 2013. 